\title{
Effect of Hydro- and Hygro-Thermal Treatments on Some Wood Properties of Pinus Radiata and Pseudotsuga Menziesii
}

\section{Utjecaj hidrotermičke i higrotermičke obrade na promatrana svojstva drva bora (Pinus radiata) i duglazije (Pseudotsuga menziesii)}

\author{
Preliminary paper • Prethodno priopćenje \\ Received-prispjelo: 28. 10. 2011. \\ Accepted-prihvaćeno: 6. 9. 2012. \\ UDK: $630 * 812.22 ; 674.032 .475 .47 ; 674.032 .475 .77$ \\ doi:10.5552/drind.2012.1133
}

\begin{abstract}
Heat treatments are related to the action of temperature in successive stages and under controlled conditions, changing the chemical structure of wood. However, the method of treatment used may have a significant effect on the properties of the heat treated wood. In order to assess the effect of the heat treatments on the wood properties, two conifer species were considered, as well as the absence of the air through water and vapor and three levels of temperature $\left(130,145\right.$ and $\left.160^{\circ} \mathrm{C}\right)$. The experiments resulted in twelve treatments or interactions plus controls. This study describes the changes in chemical composition of wood at relatively low temperatures and its interactions with the physical and mechanical properties of the new thermally-modified wood. The analysis of the results indicates that the extractives and degradation products that remain in the wood processed in a closed reactor seem to be a very important factor affecting the results.
\end{abstract}

Keywords: heat treatment, extractives, shrinkage, modulus of elasticity

SAŽETAK - Toplinske obrade povezane su s djelovanjem temperature u kontroliranim uvjetima pri čemu se mijenja kemijska struktura drva. Međutim, upotrijebljena metoda toplinske obrade može imati znatan učinak na svojstva toplinski obrađenog drva. Kako bi se procijenio učinak toplinske obrade na svojstva drva, napravljen je eksperiment na dvije vrste drva četinjača, koje su obrađene uz odsutnost zraka upotrebom vode $i$ pare te pri tri različite temperature $\left(130,145\right.$ i $\left.160^{\circ} \mathrm{C}\right)$. Eksperiment je napravljen uz dvanaest kombinacija uvjeta obrade te na kontrolnom uzorku. U radu se opisuju promjene kemijskog sastava drva pri relativno niskim temperaturama $i$ interakcije tih promjena s promjenama fizikalnih i mehaničkih svojstava toplinski modificiranog drva. Analiza rezultata pokazuje da su ekstraktivne tvari i tvari nastale u drvu pri procesu toplinske modifikacije vrlo važni činitelji koji utječu na fizikalna i mehanička svojstva drva.

Ključne riječi: toplinska obrada, ekstraktivne tvari, utezanje, modul elastičnosti

\footnotetext{
${ }^{1}$ Authors are assistant professors at the Faculty of Forest Science and Natural Resources, Institute of Forest Products Technology, Austral University of Chile, Valdivia, Chile.

Autori su docenti Odjela za tehnologiju šumskih prozvoda na Fakultetu šumarske znanosti i prirodnih resursa, Australsko sveučilište u Čileu, Valdivia, Čile.
} 


\section{INTRODUCTION}

\section{UVOD}

Heat treatments are based on the action of temperature in successive stages and under controlled conditions, changing the polymeric chemical structures of wood. In general, these treatments cause the wood to exhibit a small loss in strength, in exchange for increased dimensional stability, aesthetic improvements and increased durability.

These improvements were explained through the degradation of pentosans to aldehydes and subsequent condensation of these carbonyl groups to the components of lignin phenols, thus generating a hydrophobic complex that improves the natural properties of wood. The modification of polymers should be done at relatively mild temperatures. When increasing the temperature, side-reactions begin to happen, whereby the pentosans, instead of being transformed into aldehydes, are converted into acids, which catalyze chemical degradation of all polymeric structures of wood (Mohebby, 2003).

However, the method of treatment may have a significant effect on the properties of the heat treated wood. Differences between the processes may be related to the process conditions, i.e. the heating of wood in a sealed reactor allows for the build-up of degradation products that can affect the chemical changes taking place in the wood (Stamm, 1956).

Therefore, the main objective of this study was to assess the influence of thermal treatments, in a closed reactor using a low range of temperature in the absence of the air through water and vapor, on some wood properties of Pinus radiata and Pseudotsuga menziesii.

\section{MATERIAL AND METHODS} 2. MATERIJAL I METODE

Pinus radiata and Pseudotsuga menziesii wood was supplied by a wood industry. Samples $(70 \times 70 \times$ $100 \mathrm{~mm}$ ) were obtained from both species, and a total of 56 samples were prepared for this experiment. The samples were used to assess the wood properties before the heat treatments, as well as to assess the influence of heat treatments on the properties of modified wood.

In this study, an autoclave was used with a capacity of 2001 with a maximum temperature of $160^{\circ} \mathrm{C}$. A wood dryer was also used. Appropriate instrumentation and equipment were used to characterize chemically the wood, as well as its physical and mechanical properties.

The experimental design used in this study, see Table 1, considered the following variables to assess the effect of heat treatments on wood properties: two species (Pinus radiata and Pseudotsuga menziesii), the absence of the air through water and vapor (hydrothermal and hygrothermal) and three levels of temperature $\left(130,145\right.$ and $\left.160{ }^{\circ} \mathrm{C}\right)$, with each level of temperature being applied for five hours. The experiments resulted in twelve treatments or interactions plus controls. Subsequently, the heat treated wood was dried until reaching an equilibrium moisture content (EMC) near to
Table 1 Experimental designs and resulting treatments or interactions

Tablica 1. Parametri eksperimenta i rezultirajuće obrade odnosno interakcije

\begin{tabular}{|c|c|c|c|}
\hline \multicolumn{2}{|c|}{$\begin{array}{l}\text { Heat treatments } \\
\text { Toplinska obrada }\end{array}$} & \multirow[t]{2}{*}{$\begin{array}{l}\text { Species } \\
\text { Vrsta }\end{array}$} & \multirow{2}{*}{$\begin{array}{c}\text { Treat- } \\
\text { ment } \\
\text { Code } \\
\text { Ozna- } \\
k a \\
\text { obrade }\end{array}$} \\
\hline $\begin{array}{c}\text { Absence of } \\
\text { air through } \\
\text { Odsutnost } \\
\text { zraka uz } \\
\text { upotrebu }\end{array}$ & $\begin{array}{c}\text { Tempera- } \\
\text { ture, }{ }^{\circ} \mathbf{C} \\
\text { Tempera- } \\
\text { tura, }{ }^{\circ} \mathrm{C}\end{array}$ & & \\
\hline \multirow{2}{*}{\multicolumn{2}{|c|}{$\begin{array}{l}\text { without treatment / bez } \\
\text { obrade }\end{array}$}} & Pinus radiata (control) & $\mathrm{C} 1$ \\
\hline & & $\begin{array}{l}\text { Pseudotzuga menziesii } \\
\text { (control) }\end{array}$ & $\mathrm{C} 2$ \\
\hline \multirow{3}{*}{$\begin{array}{l}\text { water } \\
\text { vode }\end{array}$} & 130 & Pinus radiata & 1 \\
\hline & 145 & Pinus radiata & 2 \\
\hline & 160 & Pinus radiata & 3 \\
\hline \multirow{3}{*}{$\begin{array}{l}\text { water } \\
\text { vode }\end{array}$} & 130 & Pseudotzuga menziesii & 4 \\
\hline & 145 & Pseudotzuga menziesii & 5 \\
\hline & 160 & Pseudotzuga menziesii & 6 \\
\hline \multirow{3}{*}{$\begin{array}{l}\text { vapor } \\
\text { pare }\end{array}$} & 130 & Pinus radiata & 7 \\
\hline & 145 & Pinus radiata & 8 \\
\hline & 160 & Pinus radiata & 9 \\
\hline \multirow{3}{*}{$\begin{array}{l}\text { vapor } \\
\text { pare }\end{array}$} & 130 & Pseudotzuga menziesii & 10 \\
\hline & 145 & Pseudotzuga menziesii & 11 \\
\hline & 160 & Pseudotzuga menziesii & 12 \\
\hline
\end{tabular}

$10 \%$. The wood was then put inside an oven for two hours at $200{ }^{\circ} \mathrm{C}$ to consolidate the new polymeric structures (Militz, 2002).

Finally, steam conditioning was applied to restore an EMC ranging between 8 to $10 \%$, allowing for the heat treated wood to be machined afterwards.

The characterization of wood before and after the heat treatment is described as follows. Chemical composition: solvent extractives in boiling water, and ethanol toluene according to TAPPI T 204-om-88.1 \% sodium hydroxide solubility TAPPI T 212-os-76 and lignin (TAPPI T 222 om-88); Physical and Mechanical properties: moisture content, anhydrous density, tangential and radial shrinkage by NCh176/1, 2 and 3 were determined; tests for MOE were also conducted using standard DIN 52186.

For the analysis, the results were processed to know their distribution and decide on the use of parametric or non parametric statistics.

\section{RESULTS AND DISCUSSION} 3. REZULTATI I RASPRAVA

\subsection{Chemical changes in wood by hydro- and} hygro-thermal treatments

3.1. Kemijske promjene u drvu nakon hidrotermičke i higrotermičke obrade

Table 2 shows an average increase of total extractives content, $1 \%$ sodium hydroxide solubility and lignin values in heat treated wood, in comparison with the controls for both conifer species.

However, when comparing between heat treatments, both Pinus radiate and Pseudotsuga menziesii show that total extractive content values tend to decre- 
Table 2 Chemical analysis of hydro- and hygro-thermal treated wood

Tablica 2. Kemijska analiza hidrotermički i higrotermički obrađenog drva

\begin{tabular}{|c|c|c|c|c|c|c|c|c|}
\hline \multicolumn{2}{|c|}{$\begin{array}{l}\text { Heat treatment } \\
\text { Toplinska obrada }\end{array}$} & \multirow[b]{2}{*}{$\begin{array}{l}\text { Species } \\
\text { Vrsta }\end{array}$} & \multirow{2}{*}{$\begin{array}{c}\text { Treat- } \\
\text { ment } \\
\text { code } \\
\text { Ozna- } \\
k a \\
\text { obrade }\end{array}$} & \multicolumn{5}{|c|}{$\begin{array}{c}\text { Chemical composition, \% } \\
\text { Kemijski sastav, \% }\end{array}$} \\
\hline $\begin{array}{l}\text { Absence of } \\
\text { air through } \\
\text { Odsutnost } \\
\text { zraka uz } \\
\text { upotrebu }\end{array}$ & $\begin{array}{c}\text { Tempera- } \\
\text { ture, }{ }^{\circ} \mathbf{C} \\
\text { Tempera- } \\
\text { tura, }{ }^{\circ} \mathrm{C}\end{array}$ & & & $\begin{array}{c}\text { Boiling } \\
\text { water } \\
\text { extractives } \\
\text { Ekstraktivi } u \\
\text { kipućoj vodi }\end{array}$ & $\begin{array}{c}\text { Ethanol } \\
\text { toluene } \\
\text { extractives } \\
\text { Ekstraktivi } u \\
\text { etanol toluenu }\end{array}$ & $\begin{array}{c}\text { Total } \\
\text { extracti- } \\
\text { ves } \\
\text { Ukupno } \\
\text { ekstraktivi }\end{array}$ & $\begin{array}{c}1 \% \text { sodium } \\
\text { hydroxide } \\
\text { solubility } \\
1 \% \text { Otopina } \\
\text { natrijeva hidroksida }\end{array}$ & $\begin{array}{l}\text { Lignin } \\
\text { Lignin }\end{array}$ \\
\hline \multirow{2}{*}{\multicolumn{2}{|c|}{$\begin{array}{l}\text { without treatment } \\
\text { bez obrade }\end{array}$}} & $\begin{array}{l}\text { P. radiata } \\
\text { (control) }\end{array}$ & $\mathrm{C} 1$ & 2.7 & 0.4 & 3.2 & 12.7 & 30.7 \\
\hline & & $\begin{array}{l}\text { P. menziesii } \\
\text { (control) }\end{array}$ & $\mathrm{C} 2$ & 3.7 & 2.9 & 4.7 & 12.6 & 30.9 \\
\hline \multirow{3}{*}{$\begin{array}{l}\text { water } \\
\text { vode }\end{array}$} & 130 & P. radiata & 1 & 8.8 & 5.5 & 10.2 & 21.5 & 31.1 \\
\hline & 145 & P. radiata & 2 & 9.4 & 6.9 & 10.3 & 20.3 & 34.4 \\
\hline & 160 & P. radiata & 3 & 6 & 7.4 & 9.3 & 14 & 40.3 \\
\hline \multirow{3}{*}{$\begin{array}{l}\text { water } \\
\text { vode }\end{array}$} & 130 & P. menziesii & 4 & 13.6 & 10.7 & 14.4 & 22.9 & 43.9 \\
\hline & 145 & P. menziesii & 5 & 12.1 & 11.8 & 14.2 & 20.6 & 38.7 \\
\hline & 160 & P. menziesii & 6 & 9.4 & 10.4 & 12.2 & 15.7 & 50.9 \\
\hline \multirow{3}{*}{$\begin{array}{l}\text { vapor } \\
\text { pare }\end{array}$} & 130 & P. radiata & 7 & 5 & 3.3 & 6 & 20.7 & 28.1 \\
\hline & 145 & P. radiata & 8 & 9.7 & 6.3 & 11.5 & 21.4 & 31.8 \\
\hline & 160 & P. radiata & 9 & 7.7 & 10.2 & 12.3 & 19 & 37.1 \\
\hline \multirow{3}{*}{$\begin{array}{l}\text { vapor } \\
\text { pare }\end{array}$} & 130 & P. menziesii & 10 & 8 & 4.5 & 8.3 & 18.8 & 35.3 \\
\hline & 145 & P. menziesii & 11 & 14 & 10.4 & 13.6 & 21.5 & 38.3 \\
\hline & 160 & P. menziesii & 12 & 13.8 & 14.3 & 16.2 & 21.2 & 44.4 \\
\hline
\end{tabular}

ase in water when the temperature increases. Conversely, under vapor conditions for both species, the extractive content values tend to increase.

In case of the $1 \%$ sodium hydroxide, in water as well as vapor, the values tend to decrease with the increase of temperature; the degradation of hemicellulose can be inferred because these soluble products represent the portion of holocellulose content that remains after boiling water and ethanol.

As shown in Table 2, the use of water or vapor is an important factor to be considered, because they have an effect on the chemical composition of the heat-treated wood. The results in Table 2 suggest that the water heat treatment facilitates the diffusion of degraded sugars and extractives out of the wood, unlike the vapor heat treatment where the degraded sugars and extractives remain in the wood.

Subsequently, the lignin generally increases keeping proportion with the loss of polysaccharide material in heating. Sandermann and Augustin (1964) suggest that, although lignin is thermally more stable than polysaccharide component of the cell wall, some thermal degradation of lignin occurs at relatively low temperatures, with the production of various phenolic degradation products.

3.2 Physical and mechanical changes in wood by hydro- and hygro-thermal treatments

3.2. Promjena fizikalnih i mehaničkih svojstava drva nakon hidrotermičke i higrotermičke obrade

The referential values of density of Pinus radiata and Pseudotsuga menziesii are approximately $0.45 \mathrm{~g} /$ $\mathrm{cm}^{3}$ and $0.41 \mathrm{~g} / \mathrm{cm}^{3}$, respectively, while the density of the samples for both species were $0.39 \mathrm{~g} / \mathrm{cm}^{3}$ and 0.36 $\mathrm{g} / \mathrm{cm}^{3}$, respectively (see Table 3 ). This difference is probably due to the fact that most of the wood samples came from the central part of the tree.

As shown in Table 3, the shrinkage in tangential and radial directions was improved for Pinus radiata and Pseudotsuga menziesii when using both water and vapor. In tangential directions, the control samples coincidentally had the same value for both species $(6 \%)$ and some treatments reduced this value to approximately $4 \%$. On the other hand, after some treatments, the values of control samples for Pinus radiata and Pseudotsuga menziesii (3.3\% and $3.63 \%$ ) were reduced to approximately $2.4 \%$ in the radial directions.

Table 3 also shows the modulus of elasticity (MOE) of Pinus radiata and Pseudotsuga menziesii wood after a hydro- and hygro-thermal treatment. In general, a loss in strength was observed as temperature increased for both species, either in water or vapor treatment in comparison with the control values. However, for Pinus radiata the MOE was higher at $130{ }^{\circ} \mathrm{C}$ and then decreased as a function of temperature. This behavior of MOE was also reported for Eucalyptus globules, where the apparent modulus of elasticity of the treated wood was a little bit higher than MOE of the original wood (Santos, 2000). Kim et al. 1998 found close relationship between the decrease of bending properties in MOE and the temperature in Pinus radiata wood treated at $120^{\circ} \mathrm{C}, 150{ }^{\circ} \mathrm{C}$ and $180{ }^{\circ} \mathrm{C}$ for 6 to 96 hours.

\subsection{Tangential and radial shrinkage in function of} hydro- and hygro-thermal treatment

3.3. Tangencijalno i radijalno utezanje u ovisnosti o hidrotermičkoj i higrotermičkoj obradi

Thermally treated wood shows an improvement in both tangential and radial shrinkage, however, these improvements vary depending on the treatment applied. 
Table 3 Physical and mechanical properties of hydro- and hygro-thermal treated wood

Tablica 3. Fizikalna i mehanička svojstva hidrotermički i higrotermički obrađenog drva

\begin{tabular}{|c|c|c|c|c|c|c|c|}
\hline \multicolumn{2}{|c|}{$\begin{array}{l}\text { Heat treatment } \\
\text { Toplinska obrada }\end{array}$} & \multirow{3}{*}{$\begin{array}{l}\text { Species } \\
\text { Vrsta }\end{array}$} & \multirow{3}{*}{$\begin{array}{c}\text { Treatment } \\
\text { code } \\
\text { Oznaka } \\
\text { obrade }\end{array}$} & \multicolumn{4}{|c|}{$\begin{array}{c}\text { Physical and mechanical properties } \\
\text { Fizikalna i mehanička svojstva }\end{array}$} \\
\hline \multirow{2}{*}{$\begin{array}{l}\text { Absence of } \\
\text { air through } \\
\text { Odsutnost zraka } \\
\text { uz upotrebu }\end{array}$} & \multirow{2}{*}{$\begin{array}{c}\text { Temperature, } \\
{ }^{\circ} \mathbf{C} \\
\text { Temperatura, } \\
{ }^{\circ} \mathrm{C}\end{array}$} & & & \multirow{2}{*}{$\begin{array}{c}\text { Density } \\
\text { Gustoća } \\
\mathrm{g} / \mathrm{cm}^{3}\end{array}$} & \multicolumn{2}{|c|}{$\begin{array}{l}\text { Shrinkage } \\
\text { Utezanje }\end{array}$} & \multirow{2}{*}{$\begin{array}{l}\text { MOE } \\
\text { MPa }\end{array}$} \\
\hline & & & & & $\begin{array}{c}\text { Radial } \\
\text { radijalno } \\
\%\end{array}$ & $\begin{array}{c}\text { Tangential } \\
\text { Tangencijalno } \\
\%\end{array}$ & \\
\hline \multirow{2}{*}{\multicolumn{2}{|c|}{$\begin{array}{l}\text { without treatment } \\
\text { bez obrade }\end{array}$}} & & $\mathrm{C} 1$ & 0.39 & 3.30 & 6.00 & 8728 \\
\hline & & P. menziesii (control) & $\mathrm{C} 2$ & 0.36 & 3.63 & 6.00 & 10219 \\
\hline \multirow{3}{*}{$\begin{array}{l}\text { water } \\
\text { vode }\end{array}$} & 130 & P. radiata & 1 & 0.37 & 3.24 & 5.95 & 10920 \\
\hline & 145 & P. radiata & 2 & 0.35 & 2.67 & 5.02 & 8874 \\
\hline & 160 & P. radiata & 3 & 0.38 & 3.00 & 5.70 & 7274 \\
\hline \multirow{3}{*}{$\begin{array}{l}\text { water } \\
\text { vode }\end{array}$} & 130 & P. menziesii & 4 & 0.36 & 2.62 & 4.41 & 8679 \\
\hline & 145 & P. menziesii & 5 & 0.36 & 2.74 & 4.40 & 8238 \\
\hline & 160 & P. menziesii & 6 & 0.34 & 2.74 & 4.08 & 3197 \\
\hline \multirow{3}{*}{$\begin{array}{l}\text { vapor } \\
\text { pare }\end{array}$} & 130 & P. radiata & 7 & 0.40 & 3.61 & 6.94 & 11477 \\
\hline & 145 & P. radiata & 8 & 0.36 & 2.50 & 5.24 & 9576 \\
\hline & 160 & P. radiata & 9 & 0.40 & 2.38 & 4.37 & 5279 \\
\hline \multirow{3}{*}{$\begin{array}{l}\text { vapor } \\
\text { pare }\end{array}$} & 130 & P. menziesii & 10 & 0.36 & 3.13 & 5.15 & 9993 \\
\hline & 145 & P. menziesii & 11 & 0.36 & 2.55 & 4.07 & 8963 \\
\hline & 160 & P. menziesii & 12 & 0.34 & 2.67 & 4.84 & 3481 \\
\hline
\end{tabular}

A comparison between heat treatment indicates that tangential and radial shrinkage tend to decrease as a function of temperature. This trend is altered by the effect of wood density and the total extractives content remaining after treatment. Table 3 shows that tangential shrinkage values are high in those treatments where extractives are found in smaller amounts, see Table 2. Conversely, low tangential shrinkage values are found in the treatments where there are more extractives, see Table 2.

Moreover, when comparing the two species, $\mathrm{Pseu}$ dotsuga menziesii has lower tangential shrinkage than Pinus radiate in both water and vapor. This is possibly due to the lower density of Pseudotsuga menziesii.

On the other hand, the Kruskal-Wallis test was used to compare the effect of treatments on some physical and mechanical responses in heat-treated wood, because the obtained responses did not fit a normal distribution even after transformation of the data.

The Kruskal-Wallis test compares the medians of tangential shrinkage within 12 levels of treatment. Since the $p$-value is less than 0.05 , there is statistically significant difference between the medians at a confidence level of $95.0 \%$.

Figure 1 and 2 show the behavior of tangential and radial shrinkage values, respectively, as a function of the treatments.

The Kruskal-Wallis test compares the medians, which indicate that there are significant differences between treatments. By using the medians, it is also possible to identify which group of treatment is different from the other. Figure 1 shows the treatments 11, 4, 5, 6 and 9 with similar medians. These treatments present the lower median values in tangential shrinkage than the rest of treatments. These results could be explained through the extractives contents, which are high in these treatments, see Table 2. Figures 1 and 2 also show that the lower tangential and radial shrinka- ge for Pinus radiata was the treatment that showed more total extractives content remaining for this species, the treatment 9, see Table 2. Taylor (1974) found that the removal of extractives increases the shrinkage and swelling of wood.

\subsection{Modulus of elasticity in the function of hydro-} and hygro-thermal treatment

3.4. Modul elastičnosti u ovisnosti o hidrotermičkoj i higrotermičkoj obradi

The Kruskal-Wallis test was used for both physical and mechanical properties to compare the medians of the modulus of elasticity within the 12 levels of treatment. Since the $p$-value is less than 0.05 , there is a

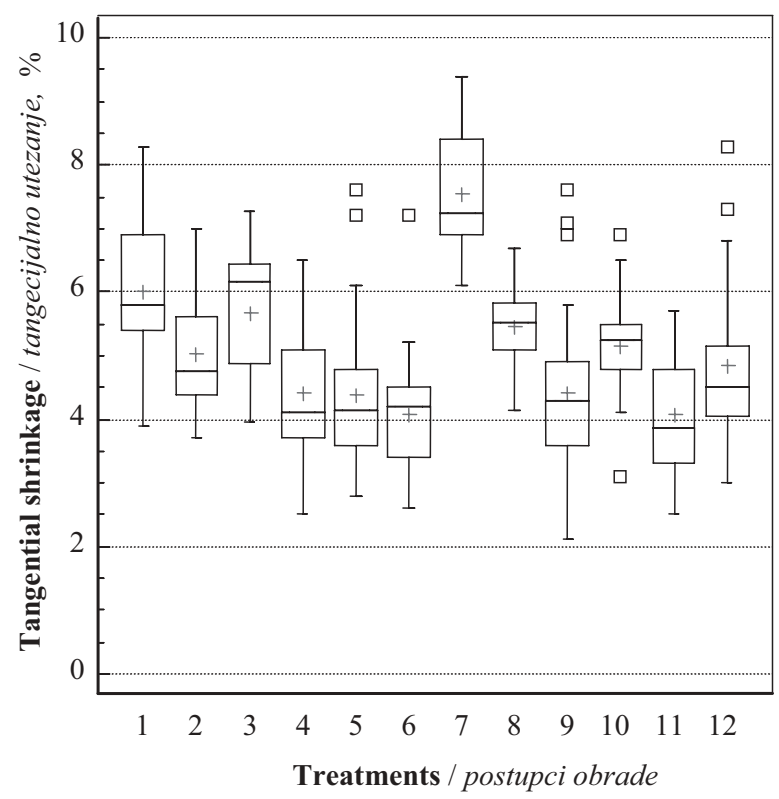

Figure 1 Tangential shrinkage after hydro- and hygro-thermal treatment

Slika 1. Tangencijalno utezanje drva nakon hidrotermičke i higrotermičke obrade 


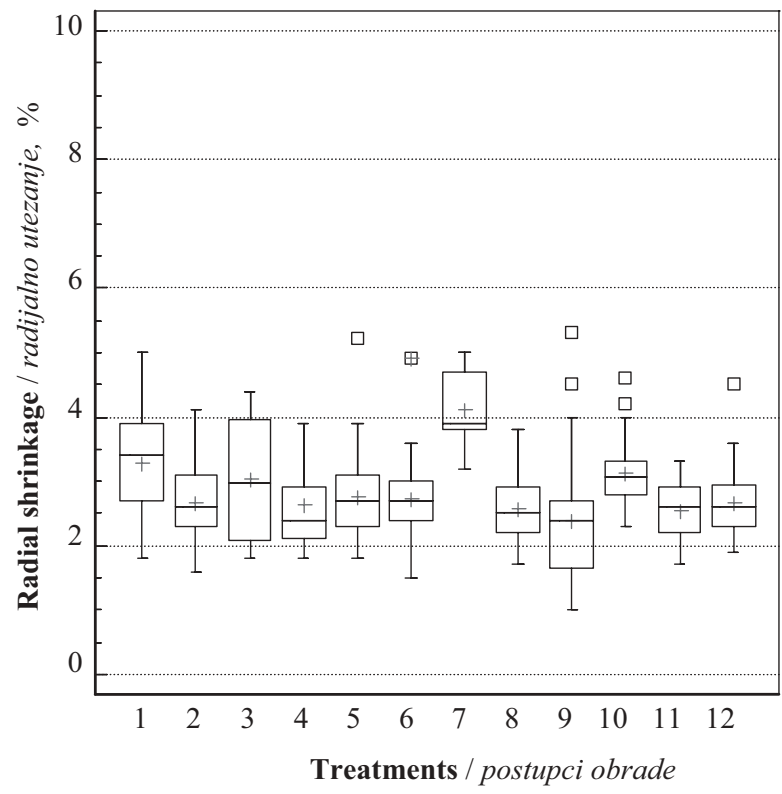

Figure 2 Radial shrinkage after hydro- and hygro-thermal treatment

Slika 2. Radijalno utezanje drva nakon hidrotermičke i higrotermičke obrade

statistically significant difference between the medians at a confidence level of $95.0 \%$. Figure 3 shows the behavior of the modulus of elasticity values as a function of the treatments.

Figure 3 shows that treatments 6 and 12 produce the lowest values of MOE. These treatments correspond to Pseudotzuga menziessii at $160{ }^{\circ} \mathrm{C}$ in water and vapor, respectively, possibly due to the lower density of this species.

In the case of Pinus radiate, treatment 9, with vapor at $160{ }^{\circ} \mathrm{C}$, showed a MOE lower than treatment 3 (water).

The differences among treatments 9 and 3 could be explained by the wood density, which was higher in

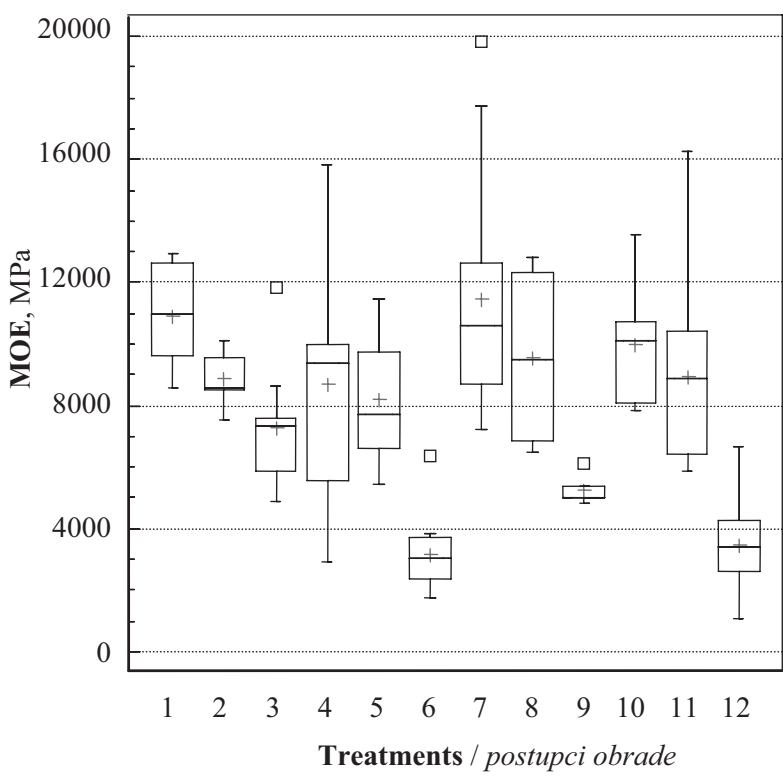

Figure 3 Modulus of elasticity of Pinus radiata and Pseudotsuga menziesii wood after hydro- and hygro-thermal treatment

Slika 3. Modul elastičnosti drva bora i duglazije nakon hidrotermičke i higrotermičke obrade samples used for the treatment 9. However, the wood samples used for treatments 12 and 6 have the same average density, and 6 produced a lower MOE than 12 , see Table 3. In this case, a possible explanation could be the high level of remaining lignin in comparison with the holocellulose, which indicates a strong degradation of those treatments when using water, see Table 2.

Finally, considering that heat treatments alter the relationship between water and wood, it is expected that a reduction in the cell wall moisture content will produce changes in mechanical properties of the wood.

\section{CONCLUSION \\ 4. ZAKLJUČAK}

Hydro- and hygro-thermal treatments have an effect on the original chemical composition and, therefore, on the properties of Pinus radiata and Pseutozuga menziesii wood.

The extractives and degradation products that remain in wood processed at low temperature range in a closed reactor seem to be a very important factor affecting the results.

\section{Acknowledgments - Zahvala}

The authors would like to thank the Internal Grant Agency DID, Austral University of Chile, Valdivia, for their financial support through grants.

\section{REFERENCES}

5. LITERATURA

1. Kim, G.; Yun, K.; Kim, J., 1998: Effect of heat treatment on decay resistance and the bending properties of radiate pine sapwood. Material und Organismen 32(2): 101-108.

2. Militz, H., 2002: Thermal treatment of wood: European processes and their background. In Proceedings of the 33rd Annual Meeting; Cardiff-Wales. 12-17.

3. Mohebby, B., 2003: Biological attack of acetylated wood. Ph.D. Thesis. Cuvillier Verlag. Göttingen. 147 p.

4. Sanderman, W.; Augustin, H., 1964: Chemical investigations on the thermal decomposition of wood. Part III: chemical investigation on the course of decomposition. Holz als Roh- und Werkstoff, 22 (10): 377-386

5. Santos, J., 2000: Mechanical behavior of Eucalyptus wood modified by heat. Wood science and technology 34: 39-43 http://dx.doi.org/10.1007/s002260050006.

6. Stamm, A.J., 1956: Thermal degradation of wood and cellulose. Industrial and Engineering Chemistry, 48(3): 413-417 http://dx.doi.org/10.1021/ie51398a022.

7. Taylor, F.W., 1974: Effect of extraction on the volume dimensions and specific gravity of solid wood blocks. Wood Sci 6:396-404.

\section{Corresponding address:}

Assist. Prof. ALDO ROLLERI, Ph.D.

Institute of Forest Products Technology

Austral University of Chile

Faculty of Forest Science and Natural Resources

Campus Isla Teja, Casilla 567

Valdivia, CHILE

e-mail: arolleri@uach.cl 